Abstracta Iranica Abstracta Iranica

Revue bibliographique pour le domaine irano-aryen

Volume 24 | 2003

Comptes rendus des publications de 2001

\title{
Dar āyene, (Naqd va barresī-ye še' $r$-e Nāder Nāderpūr). Morvārīd, 1380/2001, 237 p. [Dans le miroir]
}

\section{Christophe Balaÿ}

\section{(2) OpenEdition}

Journals

Édition électronique

URL : http://journals.openedition.org/abstractairanica/34831

ISSN : 1961-960X

Éditeur :

CNRS (UMR 7528 Mondes iraniens et indiens), Éditions de l'IFRI

Édition imprimée

Date de publication : 15 mai 2003

ISSN : 0240-8910

\section{Référence électronique}

Christophe Balaÿ, «Dar āyene, (Naqd va barresī-ye še 'r-e Nāder Nāderpūr). Morvārīd, 1380/2001,

237 p. [Dans le miroir] », Abstracta Iranica [En ligne], Volume 24 | 2003, document 292, mis en ligne le 05 janvier 2010, consulté le 25 septembre 2020. URL : http://journals.openedition.org/

abstractairanica/34831

Ce document a été généré automatiquement le 25 septembre 2020.

Tous droits réservés 


\title{
Dar āyene, (Naqd va barresī-ye še'r-e Nāder Nāderpūr). Morvārīd, 1380/2001, 237 p. [Dans le miroir]
}

\author{
Christophe Balaÿ
}

1 Étude de la poésie de Nāderpūr (1929-2000). Cet ouvrage, qui vient à publication un an après la mort du poète se veut essentiellement analytique. En trois parties, l'A. introduit le lecteur à l'œuvre d'un poète original et indépendant, à la fois novateur mais un peu à l'écart du mouvement nimaien. Amateur et fin connaisseur du domaine classique persan, mais pleinement capable de s'affranchir des modèles du passé, Nāderpūr est mort en émigration. La première partie de l'ouvrage est une belle introduction à la thématique et à la réception de l'œuvre de Nāderpūr. On y trouvera tous les éléments nécessaires à la bibliographie de son œuvre. La deuxième partie donne la parole aux poètes et aux critiques littéraires iraniens, avec notamment deux articles de Reḍā Barāhenī (repris de Ṭalā dar mes, 1992), un bel article de Yadollāh Royâ' $\overline{1}$, sur le rapport entre biographie et genèse de l'œuvre. La troisième partie est constituée de deux essais du poète lui-même sur le mouvement še'r-e now. Ces trois parties sont suivies d'une anthologie d'environ quatre-vingt pages qui donne une bonne idée de l'évolution de la poésie de Nāderpūr.

\section{INDEX}

Thèmes : 11.1.2. Littérature persane moderne 
AUTEURS

CHRISTOPHE BALÄ̈

IFRI/INALCO - Téhéran/Paris 